\title{
KUALITAS DAN FERTILITAS SPERMATOZOA SEBAGAI AKIBAT PEJANTAN BERBEDA
}

\author{
(The Quality and Fertility of Spermatozoa as a result of Different Males)
}

\author{
Mohamad Ervandi ${ }^{* 1)}$, Widiastuti Ardiansya ${ }^{1}$, Sandi Prahara ${ }^{2)}$, \\ ${ }^{1}$ Program Studi Peternakan, Fakultas Ilmu-Ilmu Pertanian, Universitas Muhammadiyah Gorontalo \\ ${ }^{2}$ Fakultas Pertanian, Universitas Ichsan Gorontalo \\ *Coresponding Author: ervandi_husain@yahoo.co.id
}

\begin{abstract}
The purpose of this study was to study the effect of male rooster species on the quality and fertility of spermatozoa. Semen is collected from Kampung, Arabic and Bangkok chickens through a massage method, while 18 female chickens are used to determine the fertility of spermatozoa through the process of hatching eggs in an incubator. The semen obtained is collected in a test tube, then diluted with Ringer's Dextrose. Spermatozoa examination is carried out macroscopically and microscopically. The study design uses a single factor design (CRD), with three (3) treatments and six (6) replications. Data analysis using variance analyst, if different followed by the smallest significant difference test. The results showed that the quality of different chicken semen was normal. volume: 0.2-0.4 ml, $\mathrm{pH}$ : 7.6-7.8, color of cement: cream, spermatozoa concentration: 2.8-3.47 $\times 10^{9} / \mathrm{ml}$, perfect mass movement $(+++)$, rate of abnormality: $2.5-3 \%$, and motility of spermatozoa: $92-93.5 \%$. The difference in men significantly affected the fertility of spermatozoa $(\mathrm{P}<0.01)$. Spermatozoa fertility values of the three males are: $68.88 \%$., $71.32 \%$., 89,96\%. Bangkok chicken has excellent semen quality, (concentration 3.47 x 108, motility 93\%), and higher fertility than Kampung and Arabic chickens
\end{abstract}

Keywords: Artificial Insemination, Chicken types, Semen Quality, Fertility.

\begin{abstract}
ABSTRAK
Tujuan penelitian untuk mempelajari pengaruh berbagai jenis ayam terhadap kualitas dan fertilitas spermatozoa. Semen ditampung dari ayam Kampung, Arab, dan Bangkok melalui metode masase, sedangkan 18 ekor ayam betina digunakan untuk menetukan fertilitas spermatozoa melalui proses menetaskan telur dalam incubator. Semen yang di peroleh, ditampung dalam tabung reaksi, selanjutnya diencerkan dengan Ringer's Dextrose. Pemeriksaan spermatozoa dilakukan secara makroskopis dan mikroskopis. Desain penelitian mengunakan Rancangan single factor (RAL), dengan tiga (3) perlakuan dan enam (6) ulangan. Analisis data menggunakan analis of varians, jika berbedanyata dilanjukan deng uji lanjut Beda Nyata Terkecil. Hasil penelitian menunjukkan bahwa kualitas semen dari ayam yang berbeda secara makroskopis adalah normal, volume 0,2-0,4 ml, pH 7.6-7.8, warna semen krem. Konsentrasi spermatozoa 2.8-3.47 × 109/ ml, gerakan masa sangat baik $(+++)$ dan tingkat abnomalitas 2,5-3\%, dan Motilitas spermatozoa 92-93,5\%. Perbedaan pejantan berpengaruh sangat nyata terhadap fertilitas spermatozoa $(\mathrm{P}<0,01)$. Nilai rataan fetilitas dari masingmasing semen adalah ayam Kampung: 68,88\%, ayam Arab: 71,32\%, ayam Bangkok: $89,96 \%$. Strain Ayam bangkok mempunyai kualitas semen sangat baik, dengan konsentrasi 3,47 x 108, motilitas 93\%, dan memiliki nilai fertilitas yang lebih baik dari ayam arab dan ayam kampung
\end{abstract}

Kata Kunci, Fertilitas, Jenis Ayam, Kualitas Semen, Inseminasi Buatan. 


\section{PENDAHULUAN}

Potensi peternakan merupakan dalam kehidupan manusia, dalam mewujudkan ketahanan pangan. Kebutuhan protein hewan sejalan dengan pertambahan jumlah penduduk, sehingga harus dipenuhi dengan ketersediaan ternak berkesinambungan. Salah satu penyedia protein hewani yang banyak tersedia adalah ternak unggas khususnya ayam kampung yang tersebar secara meluas dikalangan masyarakat perkotaan dan pedesaan. Keunggulan ayam local mampu beradaptasi dengan lingkungan, berproduksi secara maksimal dibanding dengan ternak unggas lainya. (Lawalu, dkk (2000), Kebutuhan terhadap ternak ayam yang terus meningkat, maka terbukalah peluang untuk pemuliabiakan, melalui persilangan untuk meningkatkan mutu genetic dari ayam kampung. Beberapa penelitian mengungkapakan hasil persilangan ayam kampung dan ayam ras memiliki produksi pertumbuhan yang cepat dan nilai heritabilitas dari sifat yang diturunkan sangat baik (Masili, dkk. 2018), nilai heterozigositas gen pada sifat kualitatif sangat beragam (Dako 2020). Hasil persilangan ini menghasilkan strain baru yang produktifitasnya lebih baik dari induknya. Proses persilangan dengan tujuan meningkatkan performans dapat dilakukan melalui langkah pertama seleksi, dan persilangan dengan cara melalui inseminasi buatan. Penggunann semen yang bebeda sangat penting dalam keberhasilan Inseminasi karena tingkat motilitas dan abnormalitas sperma berbeda, dan untuk menghindari inbreeding dalam polpulasi, (Ervandi, 2017). Perlakuan Inseminasi buatan dilakukan sebagai pengujian kualitas dari sifat fisik semen dimulai dari volume perejakulasi, kualitas $\mathrm{pH}$, konsentrasi, motilitas dan persentase hidup sperma, yang menggambarkan peran penggunaan pejantan, sedangakan segi reproduksi ayam betina adalah clutch, fertilisasi dan kemampuan tetas telur.

Menurut Ridwan (2002) kualitas semen menentukan persentase fertilnya telur, sebagai akibat feritlnya spermatozoa didalam semen. Rendahnya kualitas semen menyebabkan banyak telur kosong atau in fertil, sedangkan semen berkualitas akan menigkatkan jumlah telur fertil.

Apakah perbedaan bangsa ayam/jenis ayam dan strain berbeda memberikan perbedaan kualitas semen dan fetilitas sperma. perbedaan ini dapat memeberikan informasi penting terhadap fetilitas sperma dan kualitas semen, Perbedaan ini menjadi utama dalam penelitian ini dengan tujuan mengetahui kualitas semen dan fertilitas spermatozoa sebagai akibat perbedaan bangsa/jenis/ strain ayam sehingga menjadi rujukan baik peternak komersil dan juga unit pembibitan ternak ayam untuk meningkatkan angka reproduksi dan produktivitas ternak ayam.

\section{METODE PENELITIAN}

Penelitian ini dilasanakan bulan Desember 2018-Februari 2019. Sebanyak 3 ekor ayam jantan, yang berasal dari bangsa berbeda, yakni: ayam Bangkok, ayam Kampung dan 
ayam arab. Ketiga jenis ayam ini diambil semennya dengan cara masase. Ayam Ras betina digunakan sebanyak 18 ekor untuk media pelaksanaan Inseminasi Buatan (IB). Penempatan ayam dalam kandang batrei untuk memudahkan pengambilan sampel semen dan pelaksanan IB Peralatan yang digunakan tabung penampung, tabung reaksi berskala, kertas tissue, 1 set mikroskop, 1 set haemocytometer, gelas objek dan gelas penutup, kertas $\mathrm{pH}$, spuit $1 \mathrm{ml}$, gunting, Candling, mesin tetas, rak tabung. Penempatan ayam jantan dan betina didalam kandang baterai ukuran $60 \mathrm{~cm} \times 60 \mathrm{~cm}$ x $75 \mathrm{~cm}$. Pakan yang digunakan adalah pakan komersial Superfeed, jagung, dedak yang dicampur homogen $(15 \%$ : $50 \%: 35 \%)$.

Rancangan single factor (RAL) adalah disain yang digunakan dalam penelitian ini, dengan persaman linier:

$$
\mathbf{Y}_{\mathrm{ij}}=\mu+t i+\varepsilon i j
$$

$\mathrm{i}=$ perlakuan

$\mathrm{j} \quad=$ ulangani

$Y_{i j}=$ nilai perlakuan ke-i ulangan ke-j

$\mu=$ rataan umum

ti = pengaruh perlakuan ke-i

$\varepsilon i j=$ galat percobaan ke-i ulangan ke-j

Jika menunjukan pengaruh nyata, dilanjutkan dengan uji lanjut BNT. Perlakuan menggunakan ayam jantan berbeda $\mathrm{A}_{1}$ : ayam kampung, $\mathrm{A}_{2}$ : ayam arab, $\mathrm{A}_{3}$ : ayam Bangkok.

Penampungan semen dilakuan pada sore hari pukul 16:00 WITA, melalui pengurutan atau masase, pengurutan dimulai punggung belakang hingga pangkal ekor, seorang membantu proses penampungan semen dan tissue untuk membersihkan kotoran ayam.

Pengurutan diulangin 2-3 kali, hingga ayam jantan terjadi ejakulat. Dengan menggunakan tabung reaksi semen ditampung. Interval Inseminasi Buatan dan penampungan semen dilakukan setiap 3 hari sekali.

Evaluasi kualitas semen dilakukan secara makroskopis, mikroskopis dan tertilitas spermatozoa

\section{Total Konsentrasi Spermatozoa}

Menghitung spermatozoa total menggunakan formula yang disarankan Ridwan (2002)

$$
S=\frac{400}{80} \times 10 \times 200=S \times 0,0001 \text { juta spermatozoamm }
$$

Keterangan :

$\mathrm{S}=$ Total spermatozoa

\section{Motilitas Spermatozoa}

Perhitungan motilitas spermatozoa berdasarkan rumus modifikasi Ridwan (2002):

$$
\% M s=\frac{\text { Tsm }- \text { TStm }}{\mathrm{TS}} \times 100
$$

Keterangan:

Ms = Motilitas Sperma

TSm = Total Sperma motil

TStm = Total Sperma tidak motil

TS = Total Spermatoxzoa

\section{Abnormalitas Spermatozoa}

Perhitungan prersentase abnormal spermatozoa sesuai yang disarankan Ridwan (2002) adalah:

$$
A b=\frac{\mathrm{SA}}{200} \times 100
$$

Keterangan :

$\mathrm{Ab}:$ Abnormalitas Sperma

SA : Jumlah Spermatozoa Abnormalitas

\section{Konsentras Spermatozoa}


Konsentrasi spermatozoa/dosis inseminasi dihitung berdasarkan rumus yang di anjurkan oleh Kartasudjana (2001) :

$$
\text { Dosis } I B=\frac{(\mathrm{V} \times \mathrm{K} \times \mathrm{M})}{\text { Dosis IB } \times 10^{6}}
$$

Keterangan :

$\mathrm{V}$ : Volume Semen

$\mathrm{K}$ : Konsentrasi semen

M : Motilitas

\section{Fertilitas Spermatozoa}

Perkawinan antara ayam jantan dan betina dilakukan dengan teknik inseminasi buatan (AI). Pengumpulan telur selama 20 hari. Periode pengambilan telur setiap 5 hari, selanjutnya di inkubasikan dalam mesin tetas dengan $38,33^{\circ} \mathrm{C}$, kelembaban mesin tetas adalah $75 \%$. Fertilitas di amati, saat telur berumur 5 hari dalam incubator. Pengatan telur dilakukan dengan cara peneropongan terhadap telur-telur yang fertile, telur infertile dan telur kosong Fertilitas dihitung berdasarkan rumus:

$$
F s=\frac{\mathrm{TF}}{\mathrm{TDM}} \times 100
$$

Fs : Fertilitas Telur

TF : Telur Fertil

TDM : Jumlah Telur yang ditetasakan

\section{HASIL DAN PEMBAHASAN Kualitas Semen}

Kualitas semen dipengaruhi oleh: (1) Genetic. genetik berhubungan dengan pertumbuhan reproduksi. (2) Bangsa ayam. Ayam mempunyai ciri yang spesifik terhadap produksi semennya. (3) Pakan. Pembatasan pakan dilakukan terhadap calon pejantan untuk menghindari penimbunan lemak, sehingga menghambat produksi semen. (Toelihere, 1981).

Hasil evaluasi semen segar disajikan dalam tabel 1. Kualitas semen dari ketiga jenis ayam yang berbeda, secara makroskopis kondisi semen adalah normal, volume 0,2-0,4 $\mathrm{ml}, \mathrm{pH}$ 7.6-7.8, dan warna semen krem. Konsentrasi spermatozoa 2.8-3.47 $\mathrm{x}$ $10^{9} / \mathrm{ml}$, gerakan masa sangat baik $(+++)$ dan tingkat abnomalitas 2,5-3\%, dan Motilitas spermatozoa 92-93,5\%.

Kualitas semen dari ayam yang berbeda secara makroskopis adalah normal, volume 0,2-0,4 ml, pH 7.6-7.8, warna semen krem. Konsentrasi spermatozoa 2.8-3.47 x 109/ ml, gerakan masa sangat baik $(+++)$ dan tingkat abnomalitas 2,5-3\%, dan Motilitas spermatozoa $92-93,5 \%$.

\begin{tabular}{|c|c|c|c|}
\hline \multirow{2}{*}{$\begin{array}{c}\text { Pengamatan } \\
\text { Makroskopis dan MikrosKopis }\end{array}$} & \multicolumn{3}{|c|}{ Ternak } \\
\hline & $\begin{array}{c}\text { Ayam } \\
\text { Kampung }\end{array}$ & Ayam Arab & Ayam Bangkok \\
\hline \multicolumn{4}{|l|}{ Makroskopis: } \\
\hline Volume (ml) & 0,4 & 0,2 & 0,3 \\
\hline $\mathrm{pH}$ & 7,8 & 7,6 & 7,6 \\
\hline Warna & Krem & Krem & Krem \\
\hline Konsistensi & Kental & Kental & Kental \\
\hline Gerakan Massa & +++ & +++ & +++ \\
\hline \multicolumn{4}{|l|}{ Mikroskopis: } \\
\hline Konsentrasi & $2,8 \times 10^{9}$ & $3,039 \times 10^{9}$ & $3,47 \times 10^{9}$ \\
\hline Motilitas & $92 \%$ & $90,49 \%$ & $93,5 \%$ \\
\hline Abnormalitas & $2,50 \%$ & $3,00 \%$ & $2,5 \%$ \\
\hline
\end{tabular}

Tabel 1. Kualiatas Semen Berdasarkan Jenis Ayam berbeda 
Hasil penelitian ini sama dengan penelitian yang laporkan oleh Pratiwi dkk, (2019) volume semen ayam kampung: 0,23 $\pm 0,01 \mathrm{~mL}$ dan ayam merawang: 0,42 $\pm 0,04 \mathrm{~mL}$ yang lebih rendah dan SK kedu: 0,16 $\pm 0,01 \mathrm{~mL}$.

Hijriyanto

yang

mengunkapkan Rataan motilitas ayam Bangkok adalah 78,9-83,3\%,

Volume semen per-ejakulat pada unggas 0,2-0,5 $\mathrm{ml}$ (Hafez, 1993) dan Suprijatna, (2005) 0,3-1,0 $\mathrm{ml}$, sedamgkan $\mathrm{pH}$ semen 7,0-7,6 (Tolihere,1993). Utami (1995) $\mathrm{pH}$ semen 7,0-8,0 dan Johari, (2009) $\mathrm{pH}$ ayam antara 8,4-8,6. Menurut Dako, (2019) volume semen per-ejakulasi $0,25 \pm 0.03$ dan $\mathrm{pH}$ semen ayam

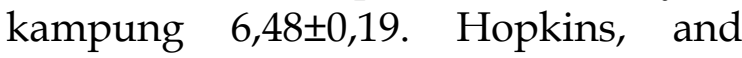
Evans (2003), setiap ejakulat semen menunjukkan 80\% motil progresif (Toelihere 1993), dan menghasilkan fertilitas $74,73 \%$.

Kualitas semen yang baik adalah berwarna krem. Warna krem yang terbentuk sebagai akibat kepadatan dan aktifitas spermatozoa dalam semen (Donoghue and Wishart 2000), dan motilitas yang baik dapat berpengaruh pada fertilitas telur. Tolihere, (1981) salah satu yang menentukan kualitas semen adalah perbedaan bangsa, sedangkan Ax, et al., (2000) volume semen tergantung bangsa dan umur ayam, proses pengambilan berulang dan ketrampilan pelaksana IB.

Menurut Junaedi, dan Husnaeni,. (2019) Ayam pelung, ayam nunukan dan ayam sentul memiliki warna semen segar berwarna putih, sedangkan ayam bangkok berwarna krem. Konsentrasi spermatozoa paling tinggi adalah ayam pelung dibanding ayam nunukan, ayam sentul dan ayam bangkok. Lebih lanjut dikatakan ayam pelung dan ayam bangkok memiliki motilitas spermatozoa lebih baik dibanding ayam nunukan dan ayam sentul. Ayam pelung dan ayam bangkok memiliki Viabilitas spermatozoa lebih baik dibanding ayam nunukan dan ayam sentul

Rusdin (2008) Konsentrasi spermatozoa hasil penelitian ini sesuai dengan yang dilaporkan oleh Sastrodiharjo dan Resnawati (2003) menyatakan konsentrasi sperma dari ayam : 2,50 - 3,50 x 109. Konsentrasi sperma dipengaruhi oleh jenis ayam, frekuensi pengambilan dan penampungan, pakan (Malecki and Martin, 2002).

Abnormalitas spermatozoa dalam penelitian ini lebiih rendah dari hasil penelitian Lubis, (2011) tingkat abnomalitas sperma ayam kampung $6,80 \pm 0,78 \%$, sedangkan abnormalitas spermatozoa ayam bangkok sebesar 10,80\% \pm 0,84, (Fitriyah, dkk, 2019).

Abnormalitas dipengaruhi gangguan patologik, pakan dan, suhu yang berubah secara ekstrim dan tidak kompotennya pelaksana (Donoghue and Wishart, 2000)

\section{Fertilitas Spermatozoa berdasarkan Jenis Ayam}

Fertilitas spermatozoa dapat diukur dengan cara menghitung jumlah telur hasil inseminasi yang fertil.

Untuk mengetahui nilai fertilitas dari telur adalah perbandingan telur fertile dan jumlah telur yang dimasukkan kedalam incubator. 
Hasil penelitian fertilitas disajikan pada tabel 2. spermatozoa dari setiap perlakuan

Tabel 2. Rataan fertilitas spermatoza ayam pada setiap perlakuan selama penelitian

\begin{tabular}{|c|c|}
\hline Perlakuan Jenis ayam & Fertilitas spermatozoa (\%) \\
\hline Kampung $\left({ }^{\Uparrow}\right)\left(\mathrm{A}_{1}\right)$ & $68,88^{\mathrm{b}}$ \\
\hline Arab $\quad\left(\delta^{\lambda}\right)\left(\mathrm{A}_{2}\right)$ & $71,32^{b}$ \\
\hline Bangkok $(\widehat{O})\left(\mathrm{A}_{3}\right)$ & $89,96^{\mathrm{a}}$ \\
\hline
\end{tabular}

Keterangan : Rataan yang diikuti dengan notasi huruf berbeda $(\mathrm{p}<0.01)$ menunjukan perbedaan sangat nyata.

Berdasarkan hasil analisis single factor menggambarkan perbedaan pejantan berpengaruh sangat nyata terhadap fertilitas spermatozoa $(\mathrm{P}<0,01)$. Hal ini disebabkan perbedaan genetic antara masing-masing pejantan. Perbedaan ini menunjukkan kemampuan dari sperma dalam membuahi sel telur, dan hasil pembuahan (zigot) dapat bertumbuh hingga 5 hari dalam incubator.

Hasil uji Lanjut menunjukkan $\mathrm{A}_{3}$ berbeda nyata $(P<0,05)$ dengan $A_{2}$ dan $A_{1}$. Sedangkan $A_{2}$ tidak berbeda nyata $(p>0,05)$ dengan $A_{1}$, Hal ini disebabkan oleh kemampuan spermatozoa saat melewati saluran reproduksi dan konsentrasi sperma dari ayam Bangkok lebih baik dibanding dengan ayam kampung dan ayam arab, selain itu secara fisik penampilan morfologi dan keberadaan ayam Bangkok sebagai ayam aduan yang memiliki proporsi tubuhnya besar akan memiliki jaringan testikular lebih baik dan dilakukan exesercise atau latihan, sehingga fertilitas spermatozoanya lebih baik dibanding dengan ayam lainya, dan juga dipengaruhi karakter seks sekunder.

Metode Ringer's dalam pengenceran untuk dosis 100 juta/inseminasi pada semen segar akan menghasilkan persentase fertilitas sebesar 72

$37 \pm 5,28 \%$ sedangkan dosis 200 juta menghasilkan fertilitas sperma sebesar $89,12 \pm 3,74 \% \quad$ (Tabatabaei, 2010), sedangkan Iswati dkk (2017) menghasilkan fertilitas spermatozoa ayam bangkok $76 \%$. Total sperma dan proses pergerakan sperma didalam saluran reproduksi mempengaruhi keberadaan spermatozoa di sperm nets (Hopkins and Evans, 2003).

Menurut Sastrodiharjo dan Resnawati (2003) menyatakan bahwa Pelaksanan Inseminasi Buatan pada ayam betina memberikan lebih banyak spermatozoa sehingga fertilitas meningkat, karena adanya penyebaran merata disaluran reproduksi dibagian Untero Vaginal Junction (UVJ), selanjunya ke Infundibulun untuk spermatozoa yang terseleksi dan terjadi fertilitas.

\section{KESIMPULAN \\ Strain Ayam bangkok} mempunyai kualitas semen sangat baik, dengan konsentrasi 3,47 × $10^{8}$, motilitas 93\%, dan memiliki nilai fertilitas yang lebih baik dari ayam arab dan ayam kampung. 


\section{DAFTAR PUSTAKA}

Ax, R. L., Dally, M., Didion, B. A., Lenz, R.W., Love, C. C., Varner, D. D., Hafez, B., and Bellin, M. E., 2000. Artificial Insemination. In: B. Hafez \& Hafez, E.S.E. (Ed.) Reproduction in Farm Animals. $7^{\text {th }}$ ed. Lippincott Williams \& Wilkins, Philadelphia.

Dako, S. (2019). Crossbreding Between Native Chiken And Leghorn Chiken Strain Isa Brown. Jurnal Peternakan, 16(1), 1-9.

Dako S., Ilham F., Laya N. K., Yusuf F.M. (2020) Inheritance of External Genetic Characteristics In Chicken Through Triple Crossing Model

Donoghue. A.M., and G.J Wishart . 2000. Storage Of Poultrysemen. Jounal AnimalReproductive Science, 62:213-232.

Ervandi, M. 2017. Motilitas dan Abnormalitas Spermatozoa Bangsa Pejantan Setelah Penyimpanan. Jurnal Akademika. 6 (2) : 113-119

Fitriyah, F., Humaidah, N., \& Suryanto, D. (2019). Pengaruh Lama Penyimpanan Semen Dalam Pengencer Ringer's Lactat Yang Disimpan Pada Suhu $4^{\circ} \mathrm{c}$ Terhadap Kualitas Spermatozoa Ayam Magon. Jurnal Rekasatwa Peternakan, 1(1).

Hafez. E.S.E. 1993. Reproduction in Farm Animal. 6 thEd. Lea and Febiger. Philadelphia.
Hijriyanto, M. (2017). Pengaruh Frekuensi Penampungan Semen Terhadap Kualitas Spermatozoa Pada Ayam Bangkok. Jurnal Ilmiah Mahasiswa Veteriner, 1(1)

Hopkins, S.M. and L.E.Evans. 2003. Artificial Inseminations. In Leslie E. Mc Donald. Veterinary Endocrinology and Reproduction. $5^{\text {th }}$ Edition.Edited by Pineda, M.H. With the editorial of Dooley M.P. Lowa State Press. USA : 391-393

Isnaini, N., dan Susilawati, T. (2017). Fertilitas Spermatozoa Ayam Buras Dengan Penambahan Antioksidan Glutathione Dalam Pengencer Ringer's Selama Simpan Dingin. Jurnal Ilmu-Ilmu Peternakan Universitas Brawijaya, 27(1), 107-115.

Junaedi, J., \& Husnaeni, H. (2019). Kaji Banding Kualitas Semen Segar Empat Genetik Ayam Lokal Indonesia (Comparative Study On The Quality Of Fresh Semen Of Four Genetic Local Chicken In Indonesia). Jurnal Veteriner, 20(3), 397-402.

Johari, S., Ondho, Y. S., Wuwuh, S., Henry, Y. B., \& Ratnaningrum, R. (2009, May). Karakteristik Dan Kualitas Semen Berbagai Galur Ayam Kedu (Characteristic and Cemen Quality at Various Lines of Kedu Chicken). In Prosiding Seminar Nasional Kebangkitan Peternakan (pp. 1-16). Fakultas Peternakan Undip. 
Kartasudjana R. 2001. Teknik Inseminasi Buatan pada Ternak.Departemen Pendidikan Nasional. Jakarta

Lubis, Triva Murtina. "Motilitas spermatozoa ayam kampung dalam pengencer air kelapa, $\mathrm{NaCl}$ fisiologis dan air kelapa- $\mathrm{NaCl}$ fisiologis pada 25-29 C." Jurnal Agripet 11.2 (2011): 45-50.

Malecki, I., and G.B Martin. 2002. Semen collection in the emu and ostrich. Proceedings of the World Ostrich Congress. Warsaw, Poland :38-43.

Masili, S., Dako, S., Ilham, F., \& Gubali, S. I. Heritabilitas Bobot Telur, Bobot Tetas Dan Bobot Badan Ayam Hasil Persilangan Umur 1 Minggu (DOC). Jambura Jounal of Animal Science. E-ISSN: 2655-2280 Volume 1 No 1.hal 1-5. DOI: https://doi.org/10.35900/jjas.v1i1 .2598

Publish: Departmen Animal Husbandry, Gorontalo State University

Pratiwi N, Yusuf T. L, Arifiantini L dan Sumantri C, 2019 Kualitas Spermatozoa dalam Modifikasi Pengencer Ringer Laktat Kuning Telur dengan Tambahan Astaxanthin dan Glutathione pada Tiga Jenis Ayam Lokal. Acta Veterinaria Indonesiana Vol. 7, No. 1: 46-54, Januari 2019, P-Issn 2337-3202, E-Issn 2337-4373
Ridwan dan Rusdin. 2008. Konservasi Semen Ayam Buras Menggunakan Berbagai Pengencer Terhadap Fertilitas Dan Periode Fertil Spermatozoa Pasca Inseminasi Buatan. Jurnal Agroland 15 (1) : 63 $-67$

Ridwan, 2002. Fertil life dan Periode Fertil Spermatozoa Ayam Buras Pasca Inseminasi Buatan. [Tesis]. Bandung. Program Pascasarjana Universitas Padjadjaran Bandung

Sankai T, H. Tsuchiya and N. Ogonuki. 2001. Shortterm nonfrozen storage of mouse epididymal spermatozoa. Therio genology 55(8) : 1759-1768.

Sastrodiharjo, S., dan H. Resnawati. 2003. Inseminasi Buatan ayam buras. Jakarta (ID): Penebar Swadaya.

Steel RGO, JH Torrie. 1991. Prinsip dan Prosedur Statistik. Edisi Kedua Gramedia. Jakarta.

Suprijatna, E., U. Atmosmarsono, dan R. Kartasudjana. 2005. Ilmu Dasar Ternak Unggas. Penebar Swadaya, Jakarta.

Tabatabaei, S. 2010. The effec Spermatozoa Number on Fertility Rate of Chicken in Artificial Insemination Programs. Journal of Animal and Veterinary Advances. 9 (12):1717-1719 
Tolihere, M.R., 1993. Inseminasi Buatan pada Ternak. Kanisiu Bandung

Utami, I. A. P. 1995. Pengaruh Berbagai Macam Pengencer Semen dan dosis inseminasi buatan terhadap fertilitas dan daya tetas telur pada ayam Buras. [Tesis]. Bogor. Progaram Intitut Pertanian Bogor. 